\title{
P04.81. Mapping the natural health landscape: New Zealand-based CAM professionals survey
}

\author{
R Vempati ${ }^{1 *}$, J Dunn ${ }^{2}$, P Cottingham ${ }^{1}$, D Sibbritt ${ }^{3}$, J Adams ${ }^{4}$ \\ From International Research Congress on Integrative Medicine and Health 2012 \\ Portland, Oregon, USA. 15-18 May 2012
}

\section{Purpose}

Complementary and Alternative Medicine (CAM) is increasing in New Zealand (NZ). As public interest in the use of CAM grows, political recognition has become increasingly topical. However, no NZ-based, empirical study of CAM professionals has been performed. The survey reported here provides a direct response to this important research gap. It examines key aspects of practice, demographics, attitudes and beliefs held about integrative medicine, CAM regulation and research attempting to quantify CAM contribution towards public health in NZ.

\section{Methods}

An online survey examined key aspects of practice, demographics, attitudes and beliefs held about integrative medicine, CAM regulation and CAM research and quantified CAM contribution towards public health in NZ. CAM practitioners were contacted via their professional bodies and individual associations. Participation response rates for individual CAM professions and CAM as a whole were calculated.

\section{Results}

200 practitioners have responded. The majority of CAM professionals are self-employed females, aged 45-54 years. Main modalities practiced are: herbal medicine, homeopathy, naturopathy, nutrition and massage with many CAM practitioners (40\%) practicing multiple modalities. The majority believe they should be integrated into main stream health care with most referring to GPs at least 1-5 times/year (49\%) and vice versa (39\%). Statutory regulation was seen as essential by $68 \%$ of CAM practitioners with $90 \%$ supporting registration either statutory or voluntary.

${ }^{1}$ Wellpark College of Natural Therapies, Auckland, New Zealand

Full list of author information is available at the end of the article

\section{Conclusion}

There is a high level of integration, in the form of referrals between primary health care physicians and CAM practitioners. Statutory CAM regulation is a pressing need to integrate with the mainstream health sector. Qualified CAM practitioners have a better understanding of research findings although they have limited ability to conduct research. The development of research capacity including CAM research funding is essential in NZ, hence local and national health care authorities need to recognize and support CAM contributions to NZ health care.

\section{Author details}

${ }^{1}$ Wellpark College of Natural Therapies, Auckland, New Zealand. ${ }^{2} \mathrm{New}$ Zealand College of Massage, Auckland, New Zealand. ${ }^{3}$ University of Newcastle, Newcastle, Australia. ${ }^{4}$ University of Technology, Sydney, Australia.

Published: 12 June 2012

doi:10.1186/1472-6882-12-S1-P351

Cite this article as: Vempati et al:: P04.81. Mapping the natural health

landscape: New Zealand-based CAM professionals survey. BMC

Complementary and Alternative Medicine 2012 12(Suppl 1):P351.

Submit your next manuscript to BioMed Central and take full advantage of:

- Convenient online submission

- Thorough peer review

- No space constraints or color figure charges

- Immediate publication on acceptance

- Inclusion in PubMed, CAS, Scopus and Google Scholar

- Research which is freely available for redistribution 